\title{
SCIDoC
}

\author{
International Journal of Dentistry and Oral Science (IJDOS) \\ ISSN: 2377-8075
}

\section{The Role of Herbs in Influencing Periodontal Health - A Systematic Review}

Research Article

\author{
Navin Anand Ingle* \\ Program Director, Dental Public Health, College of Dentistry, Riyadh Elm University, Riyadh, Saudi Arabia.
}

\section{Abstract}

Introduction: Herbal formulations have received attention in the recent past owing to its anti-inflammatory, antimicrobial and anti-oxidative effects. They can be either used alone or as a mixture in the form of dentifrices or mouth rinses. The current review aimed to assess the effectiveness and safety of various herbal formulations on gingival health.

Materials and Methods: Total 18 articles were used for data extraction; all of them were randomised controlled trials which were searched from Pubmed/Scopus published from 2001 to 2019.

Results: All the studies included showed that the herbal formulation used were effective in controlling plaque and gingivitis.

Conclusion: Herbs prove to be promising in improving oral health, either when used alone or in combination.

Keywords: Herbal Formulations; Gingival Health; Dentifrice; Mouth Rinse; Plaque.

\section{Introduction}

Herbal formulations in health sector are professed to render therapeutic benefits [1]. They are preferred as it provides benefits of natural activity, safe and lesser cost. They are even safe from adverse effects. Herbal therapy is gradually gaining popularity over modern drugs to combat side effects like antibiotic resistance.

Herbs are utilised in dentistry to treat tooth ache, gingival inflammation and canker sores [2]. Literature has shown that plant extracts exhibit antiseptic, antibacterial, antimicrobial, antifungal, antioxidant, antiviral and analgesic properties [3]. Various plant extracts like propolis, noni fruit, burdock root, neem extract, tulsi and curcumin have been tested in dentistry showing promising results [4].

The mildest form of periodontal disease is gingivitis seen as plaque accumulation on tissues of the oral cavity [5]. Dental plaque accumulation is the prime reason of all dental diseases [6]. It is described as a reversible condition, but can progress to periodontitis if not treated, resulting in bone loss and connective tissue [7]. Ideal method to remove plaque and prevent gingivitis is through mechanical plaque control such as tooth brushing and flossing. Additional oral health aides are also used like chlorhexidine, essential oils as mouthwashes which are approved by
American Dental Association as antiseptic formulations [8]. Cases of hypersensitivity, formation of stains, irritation to oral mucosa and dysguesia are reported with these usage [9]. Multiple drug resistant organisms with the use of antibiotic formulations are also increasing in the oral cavity.

Studies have demonstrated that gingivitis is associated with various systemic diseases [10]. Hence, prevention and control of gingival inflammation is imperative to maintain overall health through oral health [11].

Herbal formulations used as dentifrice or mouth rinses can be used as a single ingredient or as a combination of different medicinal plants. The aim of the review was to comprehensively present an overview on the efficacy, safety and utilization of herbal products on periodontal diseases.

\section{Materials and Methods}

A hypothesis of "Are herbal formulations effective in influencing periodontal health" was framed to be tested through this review. Literature search began by scrutinizing search engines of PubMed - Medline data base, Scopus and Journal of Web, from 2000 to 2019. Articles testing the efficacy of herbal dentifrice formula-

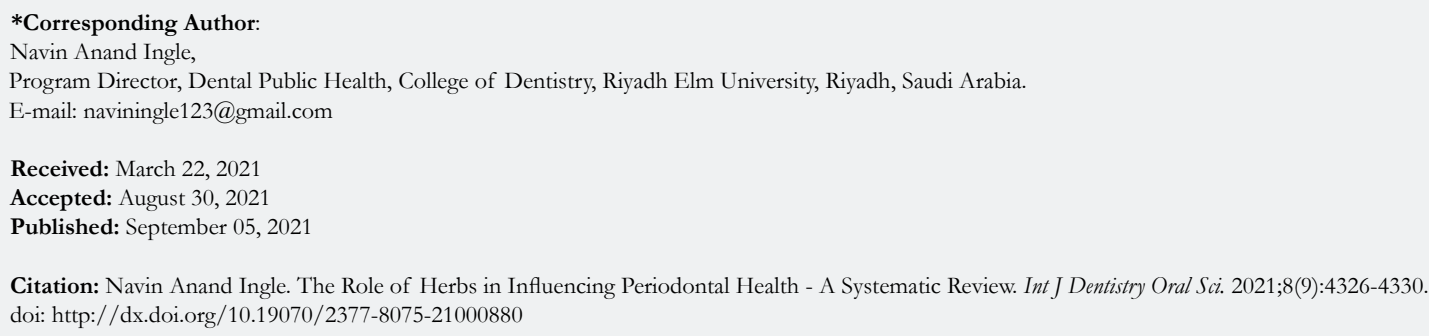

Copyright: Navin Anand Ingle ${ }^{\circ} 21$. This is an open-access article distributed under the terms of the Creative Commons Attribution License, which permits unrestricted use, distribution and reproduction in any medium, provided the original author and source are credited. 
tions of periodontal health, Randomized Controlled trials testing the herbal formulation with either a placebo or a gold standard agent were included, irrespective of the ages tested on. Review articles, unpublished data, articles without open access, dissertations and articles published in any other language apart from English were excluded. An independent researcher looked into the data base using the MeSH terms herbs, herbal dentifrice, herbal formulation, periodontitis and gingivitis.

Each selected article was reviewed for the risk of any bias by using the Cochrane Collaboration's tool for risk assessment. The search obtained was carefully scanned by the reviewer initially. Papers were chosen to be fully read only if the MeSH terms appeared in the title or abstract. The abstracts of the selected articles were then scrutinized for eligibility criteria.

Only those trials or studies which tested the herbal formulation along with a test group and subjects above 18 years of age were included for the review. Only if they fulfilled the eligibility criteria, then full text articles were read. Parameters evaluated were study design, sample size, indices recorded, herbs used and results obtained.

The search yielded a total of 327 articles, out of which 127 had to be excluded because of duplicate results. 8 articles investigated other oral diseases like premalignant lesions and dental caries and thus had to be excluded. 18 articles were included for the review finally which fulfilled the eligibility criteria (Figure 1). Outcomes in terms of disease reduction or change in indices scores was compared between the herbal component (mentioned as test group) and control group (gold standard formulation) or placebo. Risk of bias was assessed on the basis of Cochrane Collaboration into low risk, high risk or unclear risk which considered factors like Random sequence generation, allocation concealment, blinding of participants and personnel, blinding of outcome assessment, incomplete outcome data and selective reporting. Studies were included only if they had low risk of bias which independently reviewed by the author.

\section{Results}

Total 18 articles were included after full text was read independently by the reviewer. The most commonly used herbal formu- lations in oral health were dentifrices and mouthwashes. Hence, both of these were included in the review. The review of the trials included is presented in Table 1 .

Out of 18 studies reviewed, 16 were randomised controlled trial of parallel design while 2 were randomised controlled experiments of cross over type. All the included studies were double blinded. While all studies assessed periodontal disease by GI and PI, Pradeep AR et al [14] and Waghmare PF et al [25] in addition evaluated microbial colony count and George Jacob et al recorded salivary $\mathrm{pH}$. All included studies recruited individuals with gingivitis and were above 13 years. There were no significant differences in the outcome parameters evaluated between the test and control group in all studies, proving the efficacy of herbal formulation as similar to that of a gold standard formulation.

Study conducted by Kalyana Chakravarthy [12] mentioned hypersensitivity in one subject using herbal dentifrice. No other adverse effects or gingival desquamation was noted in any studies.

\section{Discussion}

The main culprit in both dental caries and gingival inflammation is dental plaque. Gingival inflammation of chronic type leads to tissue destruction which if not treated, progresses to the destroy periodontium [30]. Hence, maintaining proper oral health can control plaque and subsequently gingivitis. This is attained by efficient mechanical plaque control through toothbrushes and therapeutic toothpastes.

The use of an adjunctive antimicrobial agent in treating patients with chronic periodontitis along with scaling and root planning enhances patient outcomes when scaling alone is done [31]. Though the recent chemotherapeutic agents' project marked efficiency in bettering periodontal health, adverse effects like discoloration of teeth and mucosal surfaces, alteration of taste and increased cost cannot be overlooked. In this context herbal products are used increasingly in the recent times particularly benefitting the lower socio-economic strata across the globe [32]. Chlorhexidine, the gold standard drug, was developed way back in 1950 which still remains the most effective plaque cessation agent. But the long term usage gets restricted due its adverse effects.

Figure 1. Flow chart representing the number of articles screened and evaluated.

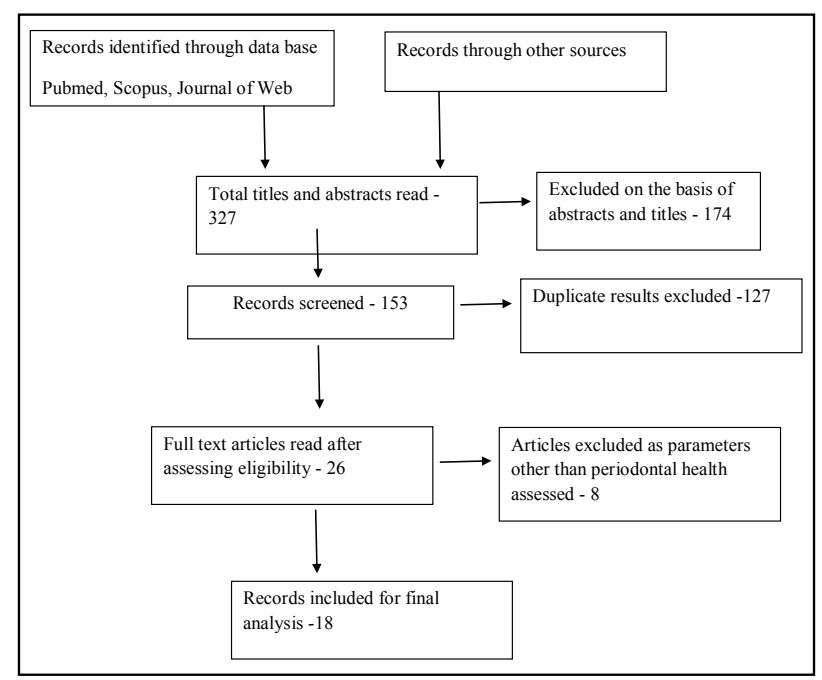


Table 1. Review of clinical trials assessing herbal formulations on gingival health.

\begin{tabular}{|c|c|c|c|c|c|c|c|}
\hline \multirow{2}{*}{ Authors / Year } & \multirow{2}{*}{ Study design } & \multirow{2}{*}{$\begin{array}{l}\text { Sample } \\
\text { Size }\end{array}$} & \multirow{2}{*}{ Age } & Tested & \multirow{2}{*}{$\begin{array}{l}\text { Study } \\
\text { duration }\end{array}$} & \multirow{2}{*}{ Index used } & \multirow{2}{*}{ Findings } \\
\hline & & & & formulation & & & \\
\hline $\begin{array}{c}\text { Kalyana } \\
\text { Chakravarthy et } \\
\text { al [12], } 2019\end{array}$ & $\begin{array}{l}\text { RCT, double } \\
\text { blind parallel } \\
\text { arm }\end{array}$ & 75 & $>18$ years & $\begin{array}{c}\text { Clove, cinnamon, } \\
\text { black pepper, bakul } \\
\text { and camphor extract } \\
\text { dentifrice }\end{array}$ & 30 days & $\begin{array}{c}\text { Turesky Gilmore } \\
\text { Glickman modifica- } \\
\text { tion of plaque index, } \\
\text { Tabott Mandel Chilton } \\
\text { modification of Loe and } \\
\text { Silness Gingival index } \\
\end{array}$ & $\begin{array}{l}\text { No significant difference in } \\
\text { clinical indices between test and } \\
\text { control group }\end{array}$ \\
\hline $\begin{array}{c}\text { Shahabe Saquib, } \\
2017[13]\end{array}$ & $\begin{array}{l}\text { RCT parallel } \\
\text { group, blinded } \\
\text { study }\end{array}$ & 112 & $\begin{array}{l}21-40 \\
\text { years }\end{array}$ & $\begin{array}{l}\text { Babul, Vajradanthi } \\
\text { and bakul }\end{array}$ & 4 weeks & Gingival Index & $\begin{array}{l}\text { Reducti } \\
\text { on in gingival inflammation was } \\
\text { similar in test and control group }\end{array}$ \\
\hline $\begin{array}{l}\text { Pradeep AR et } \\
\text { al, } 2016[14]\end{array}$ & $\begin{array}{l}\text { RCT double } \\
\text { blind parallel } \\
\text { study }\end{array}$ & 90 & & Triphala mouthwash & 60 days & $\begin{array}{c}\text { PI, GI, OHI -S, Micro- } \\
\text { biolgoic colony count }\end{array}$ & $\begin{array}{c}\text { No significant differences was } \\
\text { noticed in reduction of PI,GI, } \\
\text { OHI-S and microbiology } \\
\text { ic colony } \\
\text { count }\end{array}$ \\
\hline $\begin{array}{l}\text { Devanand } \\
\text { Gupta et al } \\
2015[15]\end{array}$ & $\begin{array}{l}\text { RCT, blinded } \\
\text { parallel study }\end{array}$ & 60 & $\begin{array}{c}20-25 \\
\text { years }\end{array}$ & $\begin{array}{l}\text { Cinnamon and } \\
\text { T.Chebula extract } \\
\text { mouthrinse }\end{array}$ & 3 days & $\begin{array}{l}\text { Turesky et al modifica- } \\
\text { tion of Quigley Hein } \\
\text { Plaque Index }\end{array}$ & $\begin{array}{l}\text { Herbal extract inhibited plaque } \\
\text { formation though not not as } \\
\text { comparable as chlorhexidine } \\
\text { mouthrinse. }\end{array}$ \\
\hline $\begin{array}{l}\text { Bhat N et al, } \\
2015[16]\end{array}$ & $\begin{array}{c}\text { RCT double } \\
\text { blind cross over } \\
\text { study }\end{array}$ & 30 & $\begin{array}{l}18-22 \\
\text { years }\end{array}$ & $\begin{array}{c}\text { Propolis and } \\
\text { Miswak mouthwash } \\
\text { (separate test groups }\end{array}$ & 24 hours & MGMPI plaque index & $\begin{array}{l}\text { MGMPI plaque score was lesser } \\
\text { in propolis followed by miswak } \\
\text { and control group }\end{array}$ \\
\hline $\begin{array}{c}\text { Aravind } \\
\text { Tatikonda et al, } \\
2014[17]\end{array}$ & $\begin{array}{l}\text { RCT double } \\
\text { blind parallel } \\
\text { study }\end{array}$ & 30 & $\begin{array}{l}35-43 \\
\text { years }\end{array}$ & Dabur red & 30 days & GI, PI & $\begin{array}{l}\text { Reduction of plaque and gingi- } \\
\text { vitis was similar in both test and } \\
\text { control groups }\end{array}$ \\
\hline $\begin{array}{l}\text { Chinani et al } \\
2014 \text { [18] }\end{array}$ & RCT & 120 & $\begin{array}{l}13-16 \\
\text { years }\end{array}$ & Herbal mouthwash & 30 days & GI, PI & $\begin{array}{l}\text { A significant reduction in GI } \\
\text { and PI scores was noted in test } \\
\text { group as effective as the control } \\
\text { group }\end{array}$ \\
\hline $\begin{array}{l}\text { Shivanand As- } \\
\text { palli et al } 2014 \\
{[19]}\end{array}$ & $\begin{array}{l}\text { RCT parallel } \\
\text { double blind }\end{array}$ & 100 & $\begin{array}{c}20-45 \\
\text { years }\end{array}$ & Herbal mouthwash & 21 days & $\begin{array}{c}\text { Gingival Index, Plaque } \\
\text { Index, Gingival Bleeding } \\
\text { Index }\end{array}$ & $\begin{array}{l}\text { Test group effectively reduced } \\
\text { plaque induced gingivitis and } \\
\text { statistically significant reduction } \\
\text { was observed in GI, BI, GBI } \\
\text { scores }\end{array}$ \\
\hline $\begin{array}{c}\text { Ajmera et al } \\
2013[20]\end{array}$ & $\mathrm{RCT}$ & 45 & $\begin{array}{l}18-65 \\
\text { years }\end{array}$ & Herbal mouthwash & & Gingival Index & $\begin{array}{l}\text { A significant reduction in gingi- } \\
\text { val inflammation }\end{array}$ \\
\hline $\begin{array}{c}\text { Makaram et al } \\
2013[21]\end{array}$ & $\begin{array}{l}\text { RCT parallel } \\
\text { study }\end{array}$ & 45 & $\begin{array}{l}11-12 \\
\text { years }\end{array}$ & $\begin{array}{l}\text { Herbal dentrifrice } \\
\text { (Barberry gel) }\end{array}$ & 20 days & GI, PI & $\begin{array}{l}\text { The test group was effective in } \\
\text { reduding gingivitis similar to the } \\
\text { control group }\end{array}$ \\
\hline $\begin{array}{c}\text { Chandrahas B, } \\
2012[22]\end{array}$ & $\begin{array}{l}\text { RCT double } \\
\text { blind }\end{array}$ & 120 & $\begin{array}{l}18-25 \\
\text { years }\end{array}$ & $\begin{array}{l}\text { Herbal mouthrinse } \\
\text { Aloevera } 100 \%\end{array}$ & 22 days & $\begin{array}{l}\text { Modified Gingival In- } \\
\text { dex, PI, Bleeding Index }\end{array}$ & $\begin{array}{l}\text { Reduction in gingival inflamma- } \\
\text { tion was noted }\end{array}$ \\
\hline $\begin{array}{c}\text { Mali et al, } 2012 \\
\text { [23] }\end{array}$ & $\begin{array}{l}\text { RCT parallel } \\
\text { double blind } \\
\text { study }\end{array}$ & 60 & $>15$ years & $\begin{array}{l}\text { Turmeric mouth } \\
\text { wash }\end{array}$ & 20 days & GI, PI & $\begin{array}{l}\text { No statistical difference be- } \\
\text { tween test and control groups }\end{array}$ \\
\hline $\begin{array}{c}\text { Tangde PS et al } \\
2012[24] \\
\end{array}$ & $\begin{array}{c}\text { RCT, double } \\
\text { blind cross over }\end{array}$ & 60 & & Herbal dentrifrice & 28 days & GI, QHI, BOP & $\begin{array}{c}\text { Significant reduction in indices } \\
\text { was noted in test group }\end{array}$ \\
\hline $\begin{array}{l}\text { Waghmare PF } \\
\text { et al, } 2011[25]\end{array}$ & $\begin{array}{l}\text { RCT, double } \\
\text { blind parallel } \\
\text { study }\end{array}$ & 100 & $\begin{array}{l}25-35 \\
\text { years }\end{array}$ & $\begin{array}{l}\text { Turmeric mouth- } \\
\text { wash }\end{array}$ & 21 days & $\begin{array}{l}\text { GI, PI, Total microbial } \\
\text { count }\end{array}$ & $\begin{array}{c}\text { No significant difference in } \\
\text { mean GI, PI and total microbial } \\
\text { count between test and control } \\
\text { group }\end{array}$ \\
\hline $\begin{array}{l}\text { Amoian B et al, } \\
2010 \text { [26] }\end{array}$ & $\begin{array}{l}\text { RCT, double } \\
\text { blind parallel } \\
\text { study } \\
\end{array}$ & 40 & & $\begin{array}{c}\text { Calendula officinalis } \\
\text { Dentrifrice }\end{array}$ & 28 days & PI,GI, BOP & $\begin{array}{l}\text { Decrease in PI, GI, BOP in } \\
\text { both test and control groups }\end{array}$ \\
\hline $\begin{array}{c}\text { George Jacob et } \\
\text { al, } 2009[27]\end{array}$ & $\begin{array}{l}\text { RCT double } \\
\text { blind parallel } \\
\text { study }\end{array}$ & 30 & $\begin{array}{l}18-65 \\
\text { years }\end{array}$ & Colgate herbal & 30 days & $\begin{array}{c}\text { Turesky modification } \\
\text { of Quigley Hein Plaque } \\
\text { Index, GI, salivary pH }\end{array}$ & $\begin{array}{l}\text { Significant reduction in PI and } \\
\text { GI, chang in salivary } \mathrm{pH} \text { was } \\
\text { not statistically significant }\end{array}$ \\
\hline $\begin{array}{l}\text { Ozaki et al, } \\
2006 \text { [28] }\end{array}$ & $\begin{array}{l}\text { RCT, double } \\
\text { blind parallel } \\
\text { study } \\
\end{array}$ & 42 & $\begin{array}{l}18-69 \\
\text { years }\end{array}$ & Paradontax & 28 days & $\begin{array}{c}\text { Turesky modification } \\
\text { of Quigley Hein Index, } \\
\text { Gingival Index } \\
\end{array}$ & $\begin{array}{l}\text { Significant reduction in PI and } \\
\text { GI in test group }\end{array}$ \\
\hline $\begin{array}{l}\text { Pannuti et al } \\
2003 \text { [29] }\end{array}$ & $\begin{array}{l}\text { RCT parallel } \\
\text { double blind }\end{array}$ & 31 & $18-35$ & Paradontax & 3 weeks & $\begin{array}{c}\text { Turesky modification } \\
\text { of Quigley Hein plaque } \\
\text { Index, GI }\end{array}$ & $\begin{array}{l}\text { No statistically significant dif- } \\
\text { ference was observed between } \\
\text { test and control groups after } \\
\text { study duration. }\end{array}$ \\
\hline
\end{tabular}


Out of the 18 articles reviewed, 16 followed the parallel design while two studies were of cross over study design. All the studies the trials were double blinded ensuring non discrepancy of study results. While the effect of herbal extract was evaluated for 24 hours by Bhat $\mathrm{N}$ etal [16] which formed the least time frame in the review, Pradeep et al [14] assessed the efficacy of Triphala formulation over 60 days on plaque. It also assessed microbiological counts in plaque. But the subjects in the study of Bhat $\mathrm{N}$ et al [16] were instructed to refrain from oral hygiene practices completely, which might have been the reason for such a short time period as obtaining patient compliance will be difficult. In both the trials mentioned, gingival inflammation reduced significantly in the test group which was as comparable to that of control group.

All the studies showed no difference between herbal extract formulations and control group in treating gingival health, excepting for the study done by Devanand et al [15] in which the herbal extract mouthrinse reduced plaque formation in slightly lesser proportion as compared to the control group.

Herbal formulations form natural photochemical which can be substituted to antibiotics and is an important alternative approach to manage oral and periodontal infections [33, 34].

Herbal components were delivered in various formulations and modes. While turmeric mouth wash was tested in studies conducted by Mali et al [23] and Waghnmore et al [25], Paradontax was tested in the studies of George Jacob [27], Ozaki [28] and Pannutti et al [29]. Barberry and Aloe vera gel was tested by Makaram [21] and Chandrahas et al [22] respectively.

Study conducted by Pannuti et al [29] and Devanand et al [15] was done on dental students. Hawthorne effect could have influenced the outcome of this study as mere participation in the trial could have improved the scores by motivating participants to adopt better oral hygiene behaviours irrespective of whichever group they were in.

The main mechanism by which herbal formulations resulted in decreasing gingival inflammation was by reducing markers of inflammation like IL - B, IL - 2,IL - 6, IFN - Y and also reduces the pathogenic bacteria count in the oral cavity.

The review results suggest that herbal formulations in any mode improved gingival health in all the studies included and also reduced the bacterial count in the plaque as seen in the study done by Pradeep et al [14]. None of the studies had followed proper sample size calculation in recruiting study participants. Also, the fact that patient compliance determined the study results must not be overlooked in any study. None of the studies were conducted for a long term, so no data regarding adverse effect of any herbal formulation related to its long term usage is available till now. Clinical trials designed with larger sample size and for a longer time frame are recommended.

\section{Conclusion}

Based on the existing clinical evidence available, the review supports the effectiveness of herbal formulations in treating gingivitis. Studies involving amalgamation of various herbs to optimise their anti - plaque potential efficacy is needed to overcome the adverse side effects associated with the conventional plaque control formulations.

\section{References}

[1]. Anand B. Herbal therapy in periodontics: a review. J Res Pharm Sci. 2017;3(5):1-7.

[2]. Kumar G, Jalaluddin M, Rout P, Mohanty R, Dileep CL. Emerging trends of herbal care in dentistry. J Clin Diagn Res. 2013 Aug;7(8):1827-9. Pubmed PMID: 24086929.

[3]. Sinha DJ, Sinha AA. Natural medicaments in dentistry. Ayu. 2014 Apr;35(2):113-8. Pubmed PMID: 25558153.

[4]. Pujar M, Makandar SD. Herbal usage in endodontics-A review. International journal of contemporary dentistry. 2011;2(1).

[5]. Pihlstrom BL, Michalowicz BS, Johnson NW. Periodontal diseases. Lancet. 2005 Nov 19;366(9499):1809-20. Pubmed PMID: 16298220.

[6]. Newman MG, Takei HH, Klokkevold PR. Carranza's Clinical Periodontology. 10th ed. New Delhi: Elsevier; 2006.

[7]. Ganavadiya R, Shekar BRC, Goel P, Hongal SG, Jain M, Gupta R. Comparison of anti-plaque efficacy between a low and high cost dentifrice: A short term randomized double-blind trial. Eur J Dent. 2014 Jul;8(3):381388. Pubmed PMID: 25202220.

[8]. Metushaj A. Epidemiology of periodontal diseases. ANGLISTICUM. Journal of the Association-Institute for English Language and American Studies. 2015 Dec 31;3(6):136-40.

[9]. Abdollahi M, Rahimi R, Radfar M. Current opinion on drug-induced oral reactions: a comprehensive review. J Contemp Dent Pract. 2008 Mar 1;9(3):1-15. Pubmed PMID: 18335114.

[10]. Beck JD, Moss KL, Morelli T, Offenbacher S. Periodontal profile class is associated with prevalent diabetes, coronary heart disease, stroke, and systemic markers of C-reactive protein and interleukin-6. J Periodontol. 2018 Feb;89(2):157-165. Pubmed PMID: 29520823.

[11]. Halawany HS. A review on miswak (Salvadora persica) and its effect on various aspects of oral health. Saudi Dent J. 2012 Apr;24(2):63-9. Pubmed PMID: 23960531.

[12]. Pentapati KC, Kukkamalla MA, Siddiq H, Sabnis N. Effectiveness of novel herbal dentifrice in control of plaque, gingivitis, and halitosis - Randomized controlled trial. J Tradit Complement Med. 2019 Jun 25;10(6):565-569. Pubmed PMID: 33134132.

[13]. Saquib S. Anti-Gingivitis Effect of an Ayurvedic Formulation Versus $0.2 \%$ Chlorhexidine on Maintenance Phase: A Randomized Clinical Trial. Journal of Basic and Clinical Pharmacy. 2017;8(4).

[14]. Pradeep AR, Suke DK, Martande SS, Singh SP, Nagpal K, Naik SB. Triphala, a New Herbal Mouthwash for the Treatment of Gingivitis: A Randomized Controlled Clinical Trial. J Periodontol. 2016 Nov;87(11):1352-1359. Pubmed PMID: 27442086.

[15]. Gupta D, Nayan S, Tippanawar HK, Patil GI, Jain A, Momin RK, et al. Are herbal mouthwash efficacious over chlorhexidine on the dental plaque? Pharmacognosy Res. 2015 Jul-Sep;7(3):277-81. Pubmed PMID: 26130940.

[16]. Bhat N, Bapat S, Asawa K, Tak M, Chaturvedi P, Gupta VV, et al. The antiplaque efficacy of propolis-based herbal toothpaste: A crossover clinical study. J Nat Sci Biol Med. 2015 Jul-Dec;6(2):364-8. Pubmed PMID: 26283831.

[17]. Tatikonda A, Debnath S, Chauhan VS, Chaurasia VR, Taranath M, Sharma AM. Effects of herbal and non-herbal toothpastes on plaque and gingivitis: A clinical comparative study. J Int Soc Prev Community Dent. 2014 Dec;4(Suppl 2):S126-9. Pubmed PMID: 25558453.

[18]. Chainani SH, Siddana S, Reddy C, Manjunathappa TH, Manjunath M, Rudraswamy S. Antiplaque and antigingivitis efficacy of triphala and chlorhexidine mouthrinse among schoolchildren - a cross-over, double-blind, randomised controlled trial. Oral Health Prev Dent. 2014;12(3):209-17. Pubmed PMID: 25197734.

[19]. Aspalli S, Shetty VS, Devarathnamma MV, Nagappa G, Archana D, Parab P. Evaluation of antiplaque and antigingivitis effect of herbal mouthwash in treatment of plaque induced gingivitis: A randomized, clinical trial. J Indian Soc Periodontol. 2014 Jan;18(1):48-52. Pubmed PMID: 24744544.

[20]. Ajmera N, Chatterjee A, Goyal V. Aloe vera: It's effect on gingivitis. J Indian Soc Periodontol. 2013 Jul;17(4):435-8. Pubmed PMID: 24174720.

[21]. Makarem A, Asodeh NK. Efficacy of barberry aqueous extracts dental gel on control of plaque and gingivitis. Acta Medica Iranica. 2007:91-4.

[22]. Chandrahas B, Jayakumar A, Naveen A, Butchibabu K, Reddy PK, Muralikrishna T. A randomized, double-blind clinical study to assess the antiplaque and antigingivitis efficacy of Aloe vera mouth rinse. J Indian Soc Periodontol. 2012 Oct;16(4):543-8. Pubmed PMID: 23493442.

[23]. Mali AM, Behal R, Gilda SS. Comparative evaluation of $0.1 \%$ turmeric mouthwash with $0.2 \%$ chlorhexidine gluconate in prevention of plaque and 
gingivitis: A clinical and microbiological study. J Indian Soc Periodontol. 2012 Jul;16(3):386-91. Pubmed PMID: 23162334.

[24]. Tangade PS, Mathur A, Tirth A, Kabasi S. Anti-gingivitis effects of Acacia arabica-containing toothpaste. Chin J Dent Res. 2012;15(1):49-53. Pubmed PMID: 22866283.

[25]. Waghmare PF, Chaudhari AU, Karhadkar VM, Jamkhande AS. Comparative evaluation of turmeric and chlorhexidine gluconate mouthwash in prevention of plaque formation and gingivitis: a clinical and microbiological study. J Contemp Dent Pract. 2011 Jul 1;12(4):221-4. Pubmed PMID: 22186854.

[26]. Amoian B, Moghadamnia AA, Mazandarani M, Amoian MM, Mehrmanesh $S$. The effect of Calendula extract toothpaste on the plaque index and bleeding in gingivitis. research Journal of medicinal plant. 2010;4(3):132-40.

[27]. George J, Hegde S, Rajesh KS, Kumar A. The efficacy of a herbal-based toothpaste in the control of plaque and gingivitis: a clinico-biochemical study. Indian J Dent Res. 2009 Oct-Dec;20(4):480-2. Pubmed PMID: 20139575.

[28]. Ozaki F, Pannuti CM, Imbronito AV, Pessotti W, Saraiva L, Freitas NM, et al. Efficacy of a herbal toothpaste on patients with established gingivitis: a randomized controlled trial. Brazilian oral research. 2006 Apr;20(2):172-7.
[29]. Pannuti CM, Mattos JP, Ranoya PN, Jesus AM, Lotufo RF, Romito GA. Clinical effect of a herbal dentifrice on the control of plaque and gingivitis: a double-blind study. Pesqui Odontol Bras. 2003 Oct-Dec;17(4):314-8. Pubmed PMID: 15107912.

[30]. Barnes VM, Richter R, DeVizio W. Comparison of the short-term antiplaque/antibacterial efficacy of two commercial dentifrices. J Clin Dent. 2010;21(4):101-4. Pubmed PMID: 21269038.

[31]. Bonito AJ, Lux L, Lohr KN. Impact of local adjuncts to scaling and root planing in periodontal disease therapy: a systematic review. J Periodontol. 2005 Aug;76(8):1227-36. Pubmed PMID: 16101353

[32]. Pandita V, Patthi B, Singla A, Singh S, Malhi R, Vashishtha V. Dentistry meets nature-role of herbs in periodontal care: A systematic review. Journal of Indian Association of Public Health Dentistry. 2014 Jul 1;12(3):148.

[33]. Kaur A, Kapoor D, Soni N, Gill S. Phytodentistry-a boon. Arch of Dent and Med Res. 2016;2(4):35-41.

[34]. Dalirsani Z, Aghazadeh M, Adibpour M, Amirchaghmaghi M, Pakfetrat A, Mozaffari PM, et al. In vitro comparison of the antimicrobial activity of ten herbal extracts against streptococcus mutatis with chlorhexidine. Journal of applied sciences. 2011;11(5):878-82. 